\title{
DESCRIPTION OF THE RESULT OF RHEUMATOID FACTOR IN MENOPAUSAL WOMEN IN SIDORAME BARAT II VILAGE ZONE VI MEDAN PERJUANGAN DISTRICT.
}

\author{
Ice Ratnalela Siregar \\ Jurusan Analis Poltekkes Kemenkes Medan
}

\begin{abstract}
Abstrak
Menopause is a condition that occur in women with thedecreasing hormone who affect on menstruation cycle to the lower level that make the menstruation can not happend again. Decreasing hormon can be one of the triggers of Rheumatoid Arthritis that caused by decreasing the imunity who make an autoimune reaction. One of the checks that can be a reference tho detect the Rheumatoid Arthritis is Rheumatoid Factor. Rheumtaoid Factor using aglutination principle between sheep erythrochytes which been fixed with human sera. The type of research that has been used is descriptive with 26 samples who get from lemeshow formula. Sera used as the material and research held at imuno-serology's Laboratorium Polytechnic of Health, Health Analyst Major Department of Medicine Medan. The purpose of this study is to determine the Rheumatoid Factor description result on menopausal women. The result who has been held show there are 10 samples that obtained positive (39\%) and 16 samples who obtained negative result $(61 \%)$
\end{abstract}

Kata Kunci : Rheumatoid Factor, Menopause

\section{PENDAHULUAN}

Kelurahan Sidorame Barat II Lingkungan VI merupakan wilayah yang berada pada Kecamatan Medan Perjuangan yang memiliki batas wilayah pada bagian Utara yaitu lingkungan IV, bagian selatan lingkungan III, bagian timur lingkungan IX dan bagian Barat adalah lingkungan VII. Lingkungan ini memiliki jumlah penduduk sebesar 1060 orang yang terdiri dari 494 orang laki-laki dan 566 orang perempuan. Jumlah Kepala keluarga di wilayah ini sebanyak $180 \mathrm{KK}$. Adapun jumlah wanita yang mengalami menopause dengan rata-rata 50 tahun ke atas (Nugroho, 2014) sebanyak 118 orang

Rheumatoid arthritis ( RA ) adalah suatu penyakit inflamasi sistemik kronik yang manifestasi utamanya adalah Poliarthritis yang progresif, akan tetapi penyakit ini juga dapat melibatkan seluruh organ tubuh. (Sudoyo, 2006)

Rheumatoid arthritis merupakan arthritis kronik kedua yang banyak dijumpai dan berdampak sekitar $1 \%$ dari populasi orang dewasa di Dunia. (Imbdoen, 2007) dan penyakit ini mempunyai perbandingan berdasarkan jenis kelamin antara laki-laki dan perempuan sebesar 1:2 hingga 1:3 antara usia 25 hingga 50 tahun (Charlish, 2010) bahkan menurut WHO beban penyakit pada bagian muskuloskeletal hingga memperoleh kecacatan di Indonesia pada tahun 2012 mencapai 3500 penduduk. (WHO, 2012)

Menurut penelitian Laboratorium Patologi Universitas Brawijaya mengatakan bahwa pada 24 pasien penderita Rheumatoid Arthritis dengan batasan umur 1660 tahun dari bulan Januari-Maret 2019 terdapat rata-rata usia sebesar 51 tahun dan sebagian besar adalah wanita menopause $(66,7 \%)$ (Ruliani, 2014)

Gejala klinis Rheumatoid Arthritis berupa Poliatrihritis yang mengakibatkan kerusakan pada rawan sendi dan tulang disekitarnya yang biasanya bersifat simetris yan memiliki kriteria dalam penentuannya dimana telah ditetapkan oleh ARA (American Rheumatism Association) seperti kaku di pagi hari, arthritis pada persendian tangan yang simetris bahkan hingga 3 daerah persendian, nodul rheumatoid serta Faktor rheumatoid yang positif (Sudoyo, 2006)

Beberapa teori berpendapat bahwa mekanisme pemicu dalam tubuh akan menyebabkan overakftivitas dalam sistem kekebalan sehingga berakibat pada sekresi cairan sinovial yang berlebihan, pembengkakan dalam sendi dan inflamasi pada lapisan synovial yang menyebabkan tulang rawan mengalami erosi. Erosi tulang rawan akan bergesekan dengan tulang lain menyebabkan erosi pada tulang sejati dan menyebabkan jaringan ikat fibrosa menggantikan tulang rawan dan kapsul sendi dan mengakibatkan pengerasan sendi yang sakit (Reeves et al, 2001)

Studi laboratorium menunjukkan terjadinya peningkatan pada nilai ESR (Eritrosit Sediment Rate) dan Rheumatoid Factor yang positif, serta terdapat temuan berupa gambaran radiologi yang menunjukkan pembengkakan pada jaringan lunak dan penyempitan ruangan persendian dengan kerusakan pada tulang rawan (Reeves et al, 2001)

Salah satu metode yang digunakan untuk pemeriksaan Rheumatoid Arthritis adalah dengan pemeriskaan Rheumatoid Factor, dimana Rheumatoid Factor ini menggunakan metode fiksasi lateks 
(Menggunakan lateks yang dilapisi oleh $\operatorname{IgG}$ manusia normal dan menggunakan IgG manusia sebagai target antigen) (Imbdoen, 2007)

Menopause atau dalam bidang medis disebut sebagai Masa klimakterium (Masa Non Reproduktif) adalah suatu periode atau keadaan yang terjadi pada wanita berupa penurunan hormon-hormon yang mempengaruhi siklus menstruasi hingga pada taraf yang sangat rendah sehingga menyebabkan menstruasi tidak dapat terjadi lagi, kejadian ini bukanlah merupakan penyakit dan umumnya hal ini wajar dialami oleh semua wanita dengan kisaran umur normal 50 tahun-an yang ditandai dengan beberapa gejala gejala fisiologi maupun psikologis (Masa Perimenopause) (Spencer, 2007)

Menopause menurut WHO sendiri adalah berhentinya menstruasi secara permanen akibat hilangnya aktivitas ovarium ditandai dengan amenore selama 12 bulan (Baziad, 2005) dan biasanya terjadi pada usia 45-50 tahun (Smart, 2015)

Gejala yang paling sering dialami oleh wanita adalah timbul tanda seperti hot flashes (rasa panas), insomnia, pengecilan payudara dan elastisitas kulit. Pencitraan menopause pasca menopause juga menunjukkan bahwa ovarium wanita pascamenopause berukuran kecil dan tidak berisi folikel (Heffner, 2006)

Penurunan Hormon seks juga menjadi pemicu yang tinggi terhadap resiko rheumatoid arthritis berdasarkan penelitian dari 185 wanita post menopausal dengan penyakit Rheumatoid arthritis dan kontrol berupa 518 wanita post menopausal bebas penyakit ditemukan bahwa sekitar $86 \%$ wanita dengan Rheumatoid Arthritis memiliki DHEA dibawah normal. (Imbdoen, 2005 )

\section{METODE}

Jenis Penelitian

Jenis penelitian yang dilakukan dalam penelitian adalah secara deskriptif, yaitu untuk menjabarkan gambaran hasil Rheumatoid Factor (RF) pada wanita menopause di Desa Sidorame Barat II lingkungan VI Kecamatan Medan Perjuangan.

Populasi

Populasi dalam penelitian ini adalah seluruh wanita berumur diatas 50 tahun dengan jumlah 118 jiwa yang terdapat pada Kelurahan Sidorame Barat II Lingkungan VI Kecamatan Medan Perjuangan.

\section{Sampel}

Total populasi yang dipakai adalah wanita yang telah mengalami menopause dengan umur diatas 50 berdasarkan survey penduduk tahun 2016. Jumlah sampel ditentukan dengan memakai inform consent dan menggunakan rumus Lemeshow dengan perhitungan sebagai berikut :

$$
\mathrm{n}=\frac{\mathrm{Z} \alpha^{2} \cdot \mathrm{p}(1-\mathrm{P}) \cdot \mathrm{N}}{\mathrm{d}^{2}(\mathrm{~N}-1)+Z \alpha^{2} \cdot \mathrm{p}(1-\mathrm{p})}
$$

\author{
Keterangan : \\ $\mathrm{n} \quad=$ Besar sampel \\ $\mathrm{Z} \alpha^{2}=$ Standar deviasi normal (1,64 atau 95\%) \\ $\mathrm{p} \quad=$ Proporsi $(0,5)$ \\ $\mathrm{N} \quad=$ Total populasi $(118)$ \\ $\mathrm{d}=$ Derajat kesalahan $(10 \%)$
}

Hasil perhitungan :

$$
\begin{gathered}
\mathrm{n}=\frac{(1,64)^{2} \cdot(0,5) \cdot(0,5) \cdot(118)}{(0,1)^{2} \cdot(118-1)+(1,64)^{2} \cdot(0,5) \cdot(0,5)} \\
\mathrm{n}=\frac{79,3432}{1,8424} \\
\mathrm{n}=43
\end{gathered}
$$

Maka, sampel yang akan dipakai berjumlah 43 jiwa Aglutinasi adalah reaksi penggumpalan antara antigen sel , mikroorganisme atau partikel yang muncul pada antibodi spesifik. Reaksi aglutinasi dibandingkan oleh interaksi antigen antibodi. (Glory Diagnostic, 2016)

Prosedur Pemeriksaan

1. Persiapkan alat, bahan dan reagensia pada suhu kamar

2. Ambil $50 \mu \mathrm{l}$ serum test dan letakkan pada lingkaran slide sekali pakai

3. Letakkan 1 tetes kontrol positif dan negatif di sebelah kanan slide secara berurutan

4. Tambahkan 1 tetes Latex reagen pada ketiga lingkaran slide .

5. Gunakan pengaduk untuk mencampur seluruh test, dan kontrol

6. Putarlah slide dan amati aglutinasi (Glory Diagnostic, 2016)

9. Interpretasi Hasil
Positif (+)
: Terjadi Aglutinasi
Negatif ( - )
: Tidak terjadi Aglutinasi

10. Analisa Data

Analisa data yang dilakukan menggunakan metode tabulasi dan disajikan dalam bentuk tabel yang dibahas berdasarkan pustaka yang ada

\section{HASIL}

\section{Hasil Penelitian}

Dari hasil penelitian yang telah dilakukan di Desa Sidorame Barat II Lingkungan VI kecamatan Medan Perjuangan di dapatkan sampel wanita menopause dengan umur diatas 50 tahun adalah sebagai berikut :

Tabel 4. 1:Tabel Hasil pemeriksaan berdasarkan Umur wanita menopause

\section{PEMBAHASAN}

Setelah dilakukan penelitian terhadap 26 sampel Wanita Menopause yang berada di Desa Sidorame Barat II Lingkungan VI kecamatan Medan Perjuangan yang telah diperiksa Rheumatoid Factornya dengan prinsip aglutinasi menggunakan Glory Diagnostic Kit diperoleh hasil pemeriksaan positif sebanyak 10 sampel (39\%) yang diantaranya wanita berumur 50-59 tahun sebanyak 6 orang, wanita berumur 60-69 tahun sebanyak 3 orang dan 
wanita berumur diatas 70 tahun sebanyak 1 orang. Sedangkan hasil negatif sebanyak 16 sampel (61\%) yang diantaranya wanita berumur 50-59 tahun sebanyak 10 orang, wanita berumur 60-69 tahun sebanyak 5 orang dan wanita berumur diatas 70 tahun sebanyak 1 orang.

Rheumatoid Arhtritis dapat terjadi akibat berbagai pemicu seperti penurunan hormon dari tubuh, keadaan tubuh yang sudah mulai tua ataupun komplikasi radang sendi yang memiliki akar permasalahan yang sama yaitu penurunan fungsi imun yang menyebabkan terjadinya kesalahan proses pada bagian sistem imun tubuh sehingga menghasilkan reaksi autoimun. Walaupun gejala radang yang dialami sendi sering sekali mengalami kemiripan contohnya: Gout arthritis ataupun Osteoarthtritis akan tetapi diagnosa penunjang berupa Rheumatoid factor dapat menjadi salah satu acuan dalam pemeriksaan Rheumatoid Arhtritis.

\section{KESIMPULAN DAN SARAN}

Kesimpulan

Dari hasil pemeriksaan Rheumatoid Factor pada wanita menopause yang berumur diatas 50 tahun ini diperoleh hasil yang positif sebanyak 10 orang (39\%) dengan rentang umur 50-59 tahun sebanyak 6 orang, wanita berumur 60-69 tahun sebanyak 3 orang dan wanita berumur diatas 70 tahun sebanyak 1 orang dang hasil negatif sebanyak 16 orang $(61 \%)$ dengan rentang umur 50-59 tahun sebanyak 10 orang, wanita berumur 60-69 tahun sebanyak 5 orang dan wanita berumur diatas 70 tahun sebanyak 1 orang.

Saran

1. Bagi Wanita Menopause yang sudah mendapatkan hasil pemeriksaan Rheumatoid Factor yang positif disarankan agar memeriksakan diri kepada dokter untuk memperoleh pengobatan ataupun terapi.

2. Bagi Wanita Menopause yang mendapatkan hasil pemeriksaan negatif diberikan pemberitahuan verbal akan kemungkinan terjadinya penyakit Rheumatoid Arthritisdan menyarankan untuk mempertahankan nutrisi yang cukup dan olahraga ringan yang teratur.

\section{DAFTAR PUSTAKA}

Baziad, Ali. 2003. Menopaude dan Andropause. Jakarta: Yayasan Bina Pustaka Sarwono Prawirohardjo.

Baziad, Ali. 2005. Bunga Rampai Obstetri dan Ginekologi sosial. Yogyakarta: Nuha Media.

Beydound, Hind. A. 2013. Reproductive history and postmenopausal rheumatoid arthritis among women 60 years or older, third national health and nutrition examination survey.

Charlish, Anne. 2010. Arthritis \& rematik. Yogyakarta: Pt. Citra Aji Parama.

Era Baru. Arthritis Rheumatoid dipicu oleh ketidakseimbangan hormon pada wanita. [Internet] http://www.erabaru.net/2016/10/19/artritisreumatoid-dipicu-oleh-ketidakseimbanganhormon-pada-wanital

Handjojo, Indro. 2004. Imunoassai terapan pada beberapa penyakit infeksi. Surabaya: Airlangga University Press.

Heffner, Linda. 2006. At a glance: sistem reproduksi. Jakarta: Erlangga.

Imbdoen, John. B. 2004. Current rheumatology diagnosis and treatment. United states: The MacGraw Hills Companies.

Miladiyah. Isnatin. 2003. Tujuan risiko dan manfaat hormon replacement therapy pada wanita menopause. vol 3. Yogyakarta: Mutiara Medika.

Naga, Sholeh. S. 2012. Buku panduan lengkap ilmu dan penyakit dalam. Yogyakarta: Diva Press.

Reid, David. M. 2008. Clinical trials in rheumatoid arthritis and osteoarthritis. London: SpringerVerlag London.

Reeves, Charlene. J. 2001. Keperawatan medikal bedah. Diterjemahkan oleh: Joko Setyono. Jakarta: Salemba Medika.

Roitt, Ivan M. 1985. Pokok-pokok Ilmu Kekebalan. Jakarta: PT.Gramedia Jakarta.

Ruliani, Hanik. 2014. Korelasi Kadar Vitamin D, dengan TNF- $\alpha$ dan Manifestasi Klinis pada pasien Arthritis Rematoid. Bandung: Jurnal Kedokteran Brawijaya, Vol. 28, No. 1 Februari 2014.

Spencer, Rebecca Fox. 2007. Menopause. diterjemahkan oleh Surapsari. Jakarta: Erlangga

Sudoyo, Aru. W. 2006. Buku Ajar Ilmu Penyakit Dalam jilid 3 edisi 4. Jakarta: Departemen Ilmu Penyakit Dalam FKUI.

Surbakti, E. B. 2005. Usia tengah baya. Jakarta: PT.Elex Media Komputindo.

Takasihaeng, Jan. 2000. Hidup sehat bagi wanita. Jakarta: PT.Kompas Medan Nusantara

Weatherby, Craig. 1999. The Arthritis Bible. United States: Rochester. 